\title{
Development of protein enriched shrimp crackers from shrimp shell wastes
}

\author{
M. Khan and A. K. M. A. Nowsad \\ ${ }^{1}$ Department of Fisheries Technology, Bangabandhu Sheikh Mujibur Rahman Agricultural University, Gazipur-1706, \\ ${ }^{2}$ Department of Fisheries Technology, Bangladesh Agricultural University, Email: nil_fish@yahoo.com
}

\begin{abstract}
A recipe of shrimp cracker (a type of crispy biscuit) enriched with shrimp shell protein was developed from underutilized shrimp shell wastes and the effects of different amount of shrimp shell powders on the quality and shelf life of the products were studied. Shrimp industry wastes (head, appendages, carapaces, and shell) were thoroughly washed, dried in hot air oven at $60^{\circ} \mathrm{C}$ for $24 \mathrm{~h}$ and ground by a blender. Fine shrimp shell powder thus obtained was used for making shrimp crackers. Hydrolyzed vegetable oil, was beaten by hand and other ingredients such as powder milk, sugar, oil, baking powder, flour and vanilla essence were mixed to make a dough. Various levels of shrimp shell powder $(5 \%, 10 \%$, and $20 \%)$ were mixed to the dough to enrich with shrimp protein. The dough was kept flatted in a tray, cut into pieces of different shape by dies and put into the oven at $100^{\circ} \mathrm{C}$ for 8 minutes. Increasing the quantity of shrimp shell powder in shrimp crackers increased the protein content but the quality in terms of taste, color and flavor was slightly decreased. Using of $10 \%$ shrimp shell powder obtained the best quality shrimp crackers, in terms of both protein enrichment and sensory quality. Quality of shrimp crackers was tested by both subjective and objective methods. Products made with $10 \%$ shrimp shell powder had an acceptable bacterial load in refrigeration up to 45 days but in room temperature up to 30 days. Low storage quality in room temperature might be due to inadequate packaging in the laboratory condition. This research revealed that high quality protein fortified shrimp crackers could be manufactured from unutilized shrimp shell wastes.
\end{abstract}

Key words: Shrimp, Shrimp industry wastes, Shrimp crackers

\section{Introduction}

Shrimp and prawn are very important products of aquaculture in Bangladesh. Total production of shrimp and prawn in Bangladesh in 2007-2008 was 2,23,095 metric tons (MT) as against 57,656 MT two decades ago (DOF, 2009). With the production of exportable frozen products, the shrimp processing industries also produce huge quantity of wastes varying from $40-80 \%$ depending upon species and process (Suparno and Nurchaya, 1984; Suparno and Susana, 1984; Suparno and Poernomo, 1992; Irianto and Giyatmi, 1997). The solid waste comprises mainly head, tail, vein/viscera and shell. In the processing factory in Bangladesh, except bigger sized head of freshwater prawn, other shrimp wastes are generally treated as garbage and dumped out side the factory premises within the compound. This unauthorized dumping of wastes has always been paving the way of serious environmental pollution. In each factory, additional manpower is employed or money spent to dispose such valuable wastes from the factory premises (Nowsad, 2005). After trimming, a 40-50\% of the shrimp is eventually wasted in the form of leg, appendages, head, shell and tail. According to an estimate, country's shrimp processing industries are dumping 30,000 tons of shrimp waste annually (Nowsad, 2005). There has been a glorious opportunity to utilize these shrimp wastes in the manufacture of value-added human food, animal and fish feed and valuable medicinal products like chitin and chitosan. With the Government support for fulfilling the requirements of FDA and EC regulations, most of the shrimp processing plants have well equipped with modern processing lines. If a normal care is taken, value-added food products can be produced within the existing process line. The products can be marketed locally or can be exported. This research aims to develop the low cost and environment-friendly techniques to utilize the waste of shrimp processing industries and to manufacture food products for human consumption. Shrimp cracker is a deep fried or baked snack food which is well known among ASEAN countries. The cracker is called 'krupuk' or 'kerupuk' in Indonesia, 'keropok' in Malaysia, 'prawn cracker' in British English and 'shrimp cracker' in American English. It is a popular snack in parts of East and South East Asia. The technology for producing shrimp cracker is very simple and it requires less complex machinery. No attempt has so far been taken to formulate and develop edible products or other value-added products from shrimp waste in Bangladesh. Considering the above facts, it was felt necessary to formulate and develop protein enriched shrimp crackers from unutilized shrimp waste. 


\section{Materials and Methods}

The experiments were conducted in the laboratories of the Department of Fisheries Technology of the Faculty of Fisheries, Bangladesh Agricultural University (BAU), Mymensingh. Shrimp wastes were collected from a processing plant, Lokpur Seafood Ltd, Khulna. Shrimp wastes were washed and immediately iced with crushed ice in an insulated ice box (Cosmos Ltd., Seol, Korea, $20 \mathrm{~kg}$ capacity) and then transported to the laboratory of the Faculty of Fisheries, BAU. Immediately after brought to the laboratory, shrimp wastes were thoroughly washed by distilled water several times. Shrimp head, shell, appendages and carapace were separated, meat was separated from shrimp head and washing was done again. They were then packed in airtight polythene pouch and frozen stored in a deep freezer at $20^{\circ} \mathrm{C}$.

\section{Chemical quality evaluation of shrimp shell wastes}

Proximate composition of shrimp shell wastes was determined as crude protein (AOAC, 1990), crude lipid (Bligh and Dyer, 1959), ash (AOAC, 1990) and moisture (Ludorff and Meyer, 1973). Analyses were made in three replicates. In crude protein estimation, about $1 \mathrm{~g}$ of comminuted sample was employed for Kjeldahl apparatus. A factor of 6.25 was used for converting the total nitrogen to crude protein. Lipid content was determined by extracting a given quantity of sample with acetone in Soxhlet apparatus for 2 to 3 hours. Moisture content was determined by drying a $5 \mathrm{~g}$ sample in an oven at $105^{\circ} \mathrm{C}$ for 24 hours. Ash content was determined by igniting the sample in a muffle furnace at $550^{\circ} \mathrm{C}$ for 6 hours. The pH was determined for the homogeneous mixtures of sample and distillated water $(1: 10, \mathrm{w} / \mathrm{v})$ using a digital Mettler Toledo $\mathrm{pH}$ meter. The $\mathrm{pH}$ was measured at room temperature. Analyses were made in three replicates.

\section{Preparation of shrimp shell powder}

Shrimp crackers were produced in two steps: 1) production of shrimp shell powder from shrimp wastes; 2) production of shrimp crackers by using the prepared shrimp shell powder.

Shrimp shell wastes were thoroughly washed several times with cooled freshwater. The shrimp head were removed from the meat and washed thoroughly. Shrimp shell waste components (head, thoracic and abdominal shell, carapace, telson, appendages, antennae, maxillary case) were separated and washed again. Shrimp head and waste samples were dried in a hot air oven at $60^{\circ} \mathrm{C}$ for 24 hours. Dried shrimp head and shell waste samples were finely ground by a blender 3 times for 2-3 minutes in each time. Ground shrimp shell wastes were screened by fine mesh sieve to obtain fine shrimp shell powder. The powder was then packed in glass bottles (Fig. 1) and stored in a refrigerator at $4^{\circ} \mathrm{C}$.

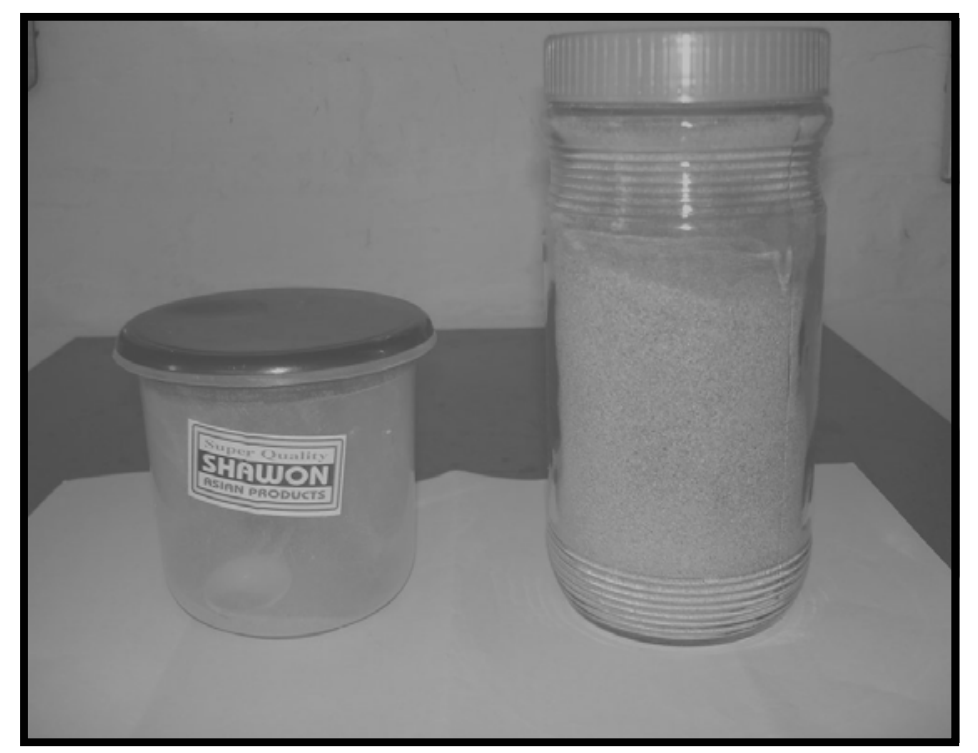

Fig. 1. Shrimp shell powder 


\section{Procedure of shrimp crackers}

For shrimp cracker preparation shrimp shell powder was mixed with the dough. Ingredients used for making shrimp cracker have been given Table 1.

Table 1. Ingredients used in shrimp cracker

\begin{tabular}{|c|c|}
\hline Ingredient & Amount (\%) \\
\hline Wheat flour & 49 \\
\hline Dalda & 19 \\
\hline Oil & 8 \\
\hline Sugar & 6 \\
\hline Ground sugar & 6 \\
\hline Milk & 6 \\
\hline Baking powder & 2 \\
\hline Salt & 0.004 \\
\hline Shrimp shell powder & $5 \%, 10 \%$ or $20 \%$ \\
\hline
\end{tabular}

Flour, liquids, leavening agent and sugars are the basic ingredients of the cracker preparation. All these ingredients function together to form the final structure of baked products. The amount and the nature of these ingredients in the recipe determine the structural and sensory characteristics of the product.

At first hydrolyzed vegetable oil or dalda was beaten by hand. It was done until dalda became completely soft or finely mixed. Some sugar was ground to fine powder and mixed with finely mixed dalda. Oil and milk powder were also added and mixing was continued. Again sugar, baking powder, salt, flours, and shrimp shell powder were added. Now 1-2 drops vanilla essence was used for flavor enhancement. After finely mixing, the dough was pressed in a flat tray and cut by different dies for different shaped crackers.

The tray was put into the oven at temperature maintained at $100^{\circ} \mathrm{C}$ for 8 minutes. After cracker preparation the tray was cooled for 3-5 minutes (Fig. 2). The crackers were then immediately packed in sealed polythene pouch or in a glass bottle for preserving crispiness.

\section{Assessment of quality of shrimp crackers}

The quality of shrimp crackers was tested by both subjective and objective methods. Subjective methods included sensory analysis, while objective methods included instrumental measurements of biochemical analysis and microbiological tests.

Sensory evaluation: A panel of nine-person of students, teachers and staffs of the Department of Fisheries Technology provided the sensory assessments of the products. Prior to testing, panelists were familiarized with the properties of shrimp crackers and the instructions relating to the scoring of the sample. Pretests were undertaken with selected samples to familiarize the panelists with the measurement procedure. Three discs of shrimp crackers were supplied to each panelist to recognize every attribute.

\section{Crispiness test}

Crispiness was defined as the amount of force required to bite through the sample with incisors. The quality was evaluated by the numerical scores up to 10 , where for C, 1=very soft; 10=extremely crispy. The panel scores were recorded in the score sheet shown in Table 2.

\section{Table 2. Scoring sheet for crispiness}

\begin{tabular}{|l|l|l|}
\hline Variable (\% of SSP) & C score (1-10) & Comments on quality \\
\hline Shrimp crackers with $5 \%$ SSP & & \\
\hline Shrimp crackers with $10 \%$ SSP & & \\
\hline Shrimp crackers with $20 \%$ SSP & & \\
\hline
\end{tabular}

\footnotetext{
${ }^{*} 1$ The averages of the 9 scores were used
} 

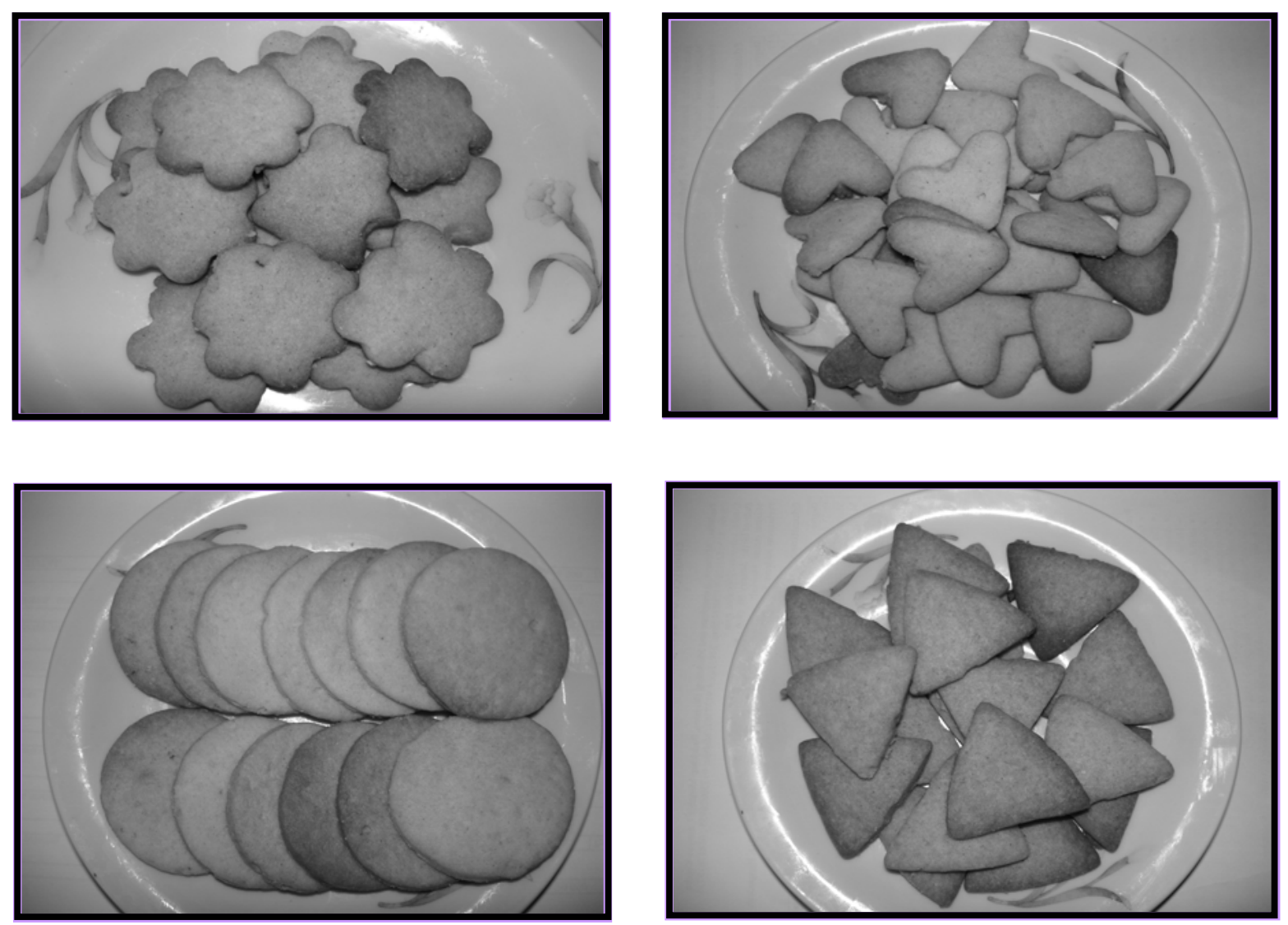

Fig. 2. Shrimp crackers in different shape

\section{Color test}

Color developed in shrimp crackers was evaluated organoleptically. Grading were used from $A^{++}$to $A$, where $\mathrm{A}^{++}=$desired color developed, $\mathrm{A}^{+}=$moderate color developed and $\mathrm{A}=$ poor color developed. The color quality was graded as in Table 3 .

Table 3. Grading used in the color of shrimp crackers

\begin{tabular}{|l|l|l|}
\hline Score and grade & Description & Comment on color quality \\
\hline 1 to $3(A)$ & Content gray colored & Poor color \\
\hline 4 to $7\left(A^{+}\right)$ & Content yellowish colored & Moderately good color \\
\hline 8 to $10\left(\mathrm{~A}^{++}\right)$ & Contents deep brown colored & Excellent color \\
\hline
\end{tabular}

\section{Biochemical test}

Proximate composition and shelf life study of shrimp crackers: Proximate composition of shrimp crackers was determined as stated before. Analyses were made in three replicates. Shrimp crackers prepared with $10 \% \mathrm{SSP}$ were stored at refrigeration temperature $\left(5^{\circ} \mathrm{C}\right)$ and at room temperature $(28$ $30^{\circ} \mathrm{C}$ ) till the study period (90 days) and the quality was evaluated in terms of the identification of bacterial load. Aerobic plate count was done by spread plate count method.

\section{Results and Discussion}

In order to understand the quality of raw material, the nutrient contents of each part of shrimp wastes were analyzed. Table 4 shows the proximate compositions and $\mathrm{pH}$ of different parts of shrimp wastes. Shrimp shell waste components were found to have very good nutritional contents. 
High levels of protein, comprising 40 to $50 \%$, were found in the shell wastes. The amount varied in different shell waste components with lowest in antennae and carapace and highest in telson. The results are in well agreement with Shahidi (1994) and Revanker (1978), who has found a 44 to $52 \%$ crude protein in shrimp's discard. Antennae which were supposed to have low nutritional content and always thrown outside or ground for silage in waste processing plants were found to have $40.7 \%$ protein on dry weight basis. Average protein content in the whole shell wastes was $45.2 \pm 1.3 \%$. This extremely high level of protein found in the shrimp wastes widened the scope of utilization of such valuable nutrient, in addition to chitin and chitosan, as functional nutritive component in human food.

Table 4. Proximate composition of different component parts of shrimp waste

\begin{tabular}{|l|c|c|c|c|}
\hline \multirow{2}{*}{ Waste } & \multicolumn{3}{|c|}{ Composition on dry weight basis (\%) } & \\
\cline { 2 - 4 } Component & Protein & Lipid & Ash & $\mathrm{pH}$ \\
\hline Thoracic \& abdominal shell & $48.5 \pm 1.3$ & $4.4 \pm 0.92$ & $22.7 \pm 0.17$ & 7.1 \\
\hline Carapace & $43.5 \pm 1.8$ & $3.8 \pm 0.33$ & $19.6 \pm 0.23$ & 7.0 \\
\hline Telson & $50.2 \pm 0.72$ & $4.5 \pm 0.71$ & $18.2 \pm 0.51$ & 7.1 \\
\hline Appendages & $48.6 \pm 0.91$ & $3.8 \pm 0.83$ & $20.3 \pm 0.78$ & 7.3 \\
\hline Antennae & $40.7 \pm 0.1$ & $3.4 \pm 0.43$ & $18.4 \pm 1.2$ & 7.2 \\
\hline Maxillary case & $47.8 \pm 0.64$ & $10.5 \pm 1.1$ & $14.6 \pm 0.97$ & 6.8 \\
\hline Head & $48.5 \pm 0.75$ & $12.8 \pm 0.95$ & $15.9 \pm 0.53$ & 6.8 \\
\hline
\end{tabular}

Mean value \pm standard error of triplicate determinations

Whole shell waste including head meat had an average lipid content of $4.1 \pm 0.5 \%$. Head had the highest lipid content of $12.8 \%$. True shell (carapace, appendages, etc) had about 3.4 to $3.8 \%$ lipid. Minerals contents in shrimp wastes were also found to be very high (Table 4).

The lipids content of shrimp head was $12.8 \%$ and that of the true shell (carapace, appendages, etc) was 3.4 to $3.8 \%$ as shown in Table 4. Jacquot (1961), Gordon and Roberts (1977) and Kinsella (1988) reported that the lipid content in shrimp shell could be related to the seasonal variations, species, physiological status, diet as well as sexual maturity of the shrimp.

The ash contents were 14.6 to $22.7 \%$ (Table 4) for the shrimp head and shell. This relatively high percentage could be attributed to the presence of some tissues within the shrimp waste residue. Shahidi (1994) found the content of ash in shrimp discards was $29.0 \pm 0.4$ on dry weight basis. Revanker (1978) reported that the percentage of total ash was as high as $19.6 \%$ for the dried shrimp waste. Protein content of shrimp head was quite high compared to the reported ranges of $8.9-23.2 \%$ in whole shrimp (Chotiyanavong, 1981) but fat content was lower than $5 \%$, therefore it was categorized as low fat.

Patcharee and Nongnuch (1990) prepared a flavoring agent from shrimp heads and the procedure is more or less similar to above procedure. Ground shrimp head $(250 \mathrm{~g})$ was blended with water, brine or dilute $\mathrm{HCl}$, incubated at optimal time and temperature. The mixture was filtered through Whatman no. 4 paper and the residue was rinsed with hot water until the filtrate was collected as $1 \mathrm{~L}$ volume. The filtrate was mixed with $10 \%$ dextrin, dextrose or sodium chloride and dried either in a hot air oven at $60^{\circ} \mathrm{C}$ or in a dehumidifier for 24 hours (dextrin), 48 hours (dextrose) and 72 hours $(\mathrm{NaCl})$. The shrimp flavor powder was kept at $4^{\circ} \mathrm{C}$ until used.

Proximate composition of shrimp shell powder was determined (Table 5 and Fig. 3 ) which was more or less similar to different parts of shrimp wastes as shown in Table 4.

Table 5. Proximate composition shrimp shell powder

\begin{tabular}{|l|c|}
\hline Component & Composition on dry weight basis (\%) \\
\hline Protein & $47.48 \pm 0.74$ \\
\hline Lipid & $10.50 \pm 0.71$ \\
\hline Ash & $19.6 \pm 0.64$ \\
\hline $\mathrm{pH}$ & $7.2 \pm 0.05$ \\
\hline
\end{tabular}

*Mean value \pm standard error of triplicate determinations 
Patcharee and Nongnuch (1990) also found almost similar values of proximate composition in shrimp flavored powder as $42 \pm 0.28 \%$ protein, $11 \pm 0.35 \%$ fat and $17 \pm 0.58 \%$ ash.

Production method of shrimp crackers was further refined, fine tuned and field validated. Patcharee and Nongnuch (1990) formulated a shrimp cracker in another method through incorporating $2 \%$ shrimp flavored powder in tapioca flour. The mixture was formed to a cylinder shape of $2.5 \mathrm{~cm}$ diameter, steamed for $30 \mathrm{~min}$, cooled and kept overnight at $4^{\circ} \mathrm{C}$. The refrigerated dough was cut into slices of 2$3 \mathrm{~mm}$ thickness, dried at $50^{\circ} \mathrm{C}$ for 12 hours and then deep fried.

As far as Bangladeshi test is concerned, products should be manufactured incorporating with known taste and flavor for domestic consumption. For this reason, the procedure of shrimp crackers preparation is not similar to the method of Patcharee and Nongnuch (1990). In this research, we used popular cracker recipe followed by the bakery industries of Bangladesh (Siddika kabir, 2004). Nutritional quality of shrimp crackers were evaluated through proximate composition. Different quantities of shrimp shell powder were used in shrimp crackers for protein enrichment. Proximate compositions of shrimp crackers have been given in Table 6 (Fig. 4).

Table 6 Proximate composition of shrimp crackers

\begin{tabular}{|l|l|l|l|}
\hline \multirow{2}{*}{ Product } & \multicolumn{3}{|c|}{ Proximate Composition (\%) on dry weight basis } \\
\cline { 2 - 4 } & Protein & Lipid & Ash \\
\hline Control crackers (0\% SSP) & $6.7 \pm 0.56$ & $30.5 \pm 0.37$ & $14.9 \pm 0.13$ \\
\hline Crackers with $5 \%$ SSP & $13.6 \pm 0.47$ & $32.1 \pm 0.61$ & $15.6 \pm 0.29$ \\
\hline Crackers with $10 \%$ SSP & $17.47 \pm 0.66$ & $33.5 \pm 0.15$ & $17.1 \pm 0.69$ \\
\hline Crackers with $20 \%$ SSP & $22.39 \pm 0.34$ & $34.7 \pm 0.59$ & $19.3 \pm 0.19$ \\
\hline
\end{tabular}

${ }^{1}$ Shrimp shell powder

Data showed that high protein content in shrimp wastes represented as the good protein source in the crackers (Table 6 and Fig. 4). In terms protein contents in three suggested shrimp cracker preparations (5\%, $10 \%$ and $20 \%$ SSP), it was found that they were $6.7 \%$ for the control crackers, while $13.6 \%, 17.47 \%$ and $22.39 \%$ for other three recipes contain 5\%, 10\% and 20\% SSP, respectively (Fig. 5). The lipid content of shrimp shell powder was $10.50 \%$ (Table 5 and Fig. 5). However, shrimp cracker contained very high amount of lipid, as high as $30-34 \%$, shrimp crackers containing higher lipid content might be in obvious reasons, due to the higher percentages of total lipids in dried shrimp head and could mainly be attributed to the lipid rich ingredients (dalda, oil) used. Ash content of shrimp crackers were about $14-19 \%$ that indicated that it also contained high level of mineral which was very important from the nutritional point of view. Percentages of ash could also be attributed to the presence of some tissues within the shrimp waste residue.

A series of experiments were conducted on different compositions of shrimp shell powder to enrich the shrimp crackers preparation. An attractive, good textured, excellent colored and nice flavored shrimp crackers were developed. Emphasis was given to add to the products Bangladeshi known taste so that the products could attract local consumer acceptances.

Sensory evaluation suggested that increasing contents of shrimp shell powder in shrimp crackers increased the protein content but the quality in terms of taste, color and flavor were decreased with the increment of SSP (Table 7). Best crackers in terms of sensory, crispiness, color, flavor and general appearance values were observed with $10 \%$ addition of SSP (Table 7). Increasing of shrimp shell powder in shrimp crackers although increased the protein content but flavor was not acceptable to the panelists. The crispiness of crackers was decreased with increasing content of shrimp shell powder.

Table 7. Effect of the SSP on sensory quality attributes of shrimp crackers

\begin{tabular}{|c|l|l|l|c|}
\hline Shrimp crackers & \multicolumn{1}{|c|}{ Crispiness } & Color & Flavor & GA \\
\hline With $5 \%$ SSP & $7.88 \pm 0.33$ & $8.25 \pm 0.17$ & $8.21 \pm 0.32$ & Good \\
\hline With $10 \%$ SSP & $8.51 \pm 0.50$ & $8.50 \pm 0.42$ & $8.25 \pm 0.63$ & Excellent \\
\hline With $20 \%$ SSP & $7.71 \pm 0.49$ & $7.77 \pm 0.31$ & $7.52 \pm 0.26$ & Good \\
\hline
\end{tabular}

$\mathrm{GA}=$ general appearance.

* Each value is mean \pm standard error of triplicate determinations 


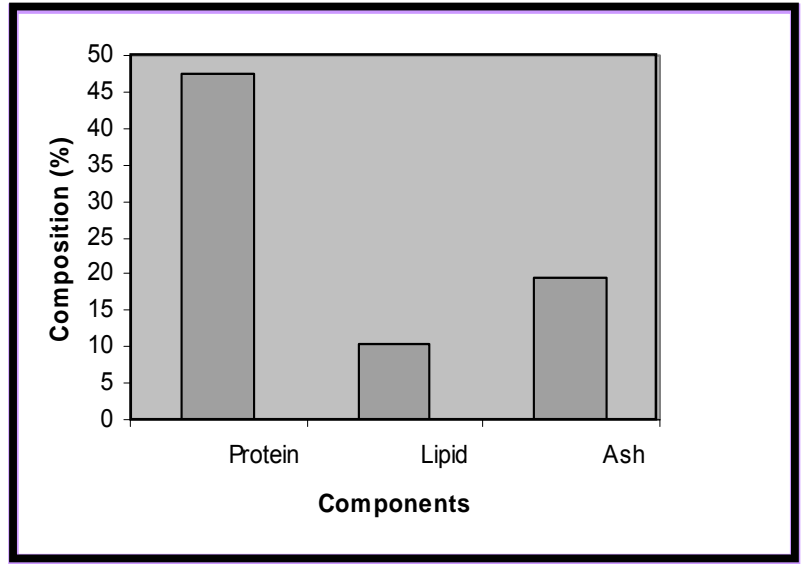

Fig. 3. Proximate composition of shrimp shell powder

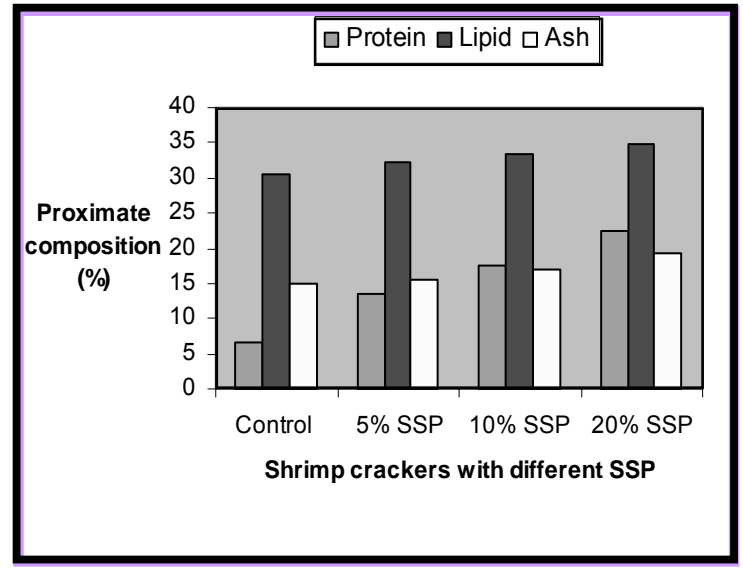

Fig. 4. Proximate composition of shrimp crackers

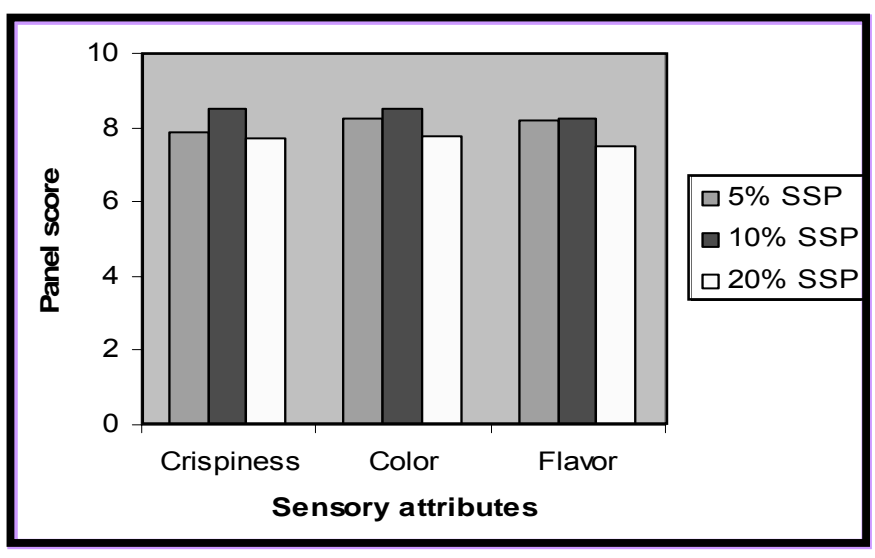

Fig. 5. Effect of the shrimp shell powder (SSP) on sensory quality attributes of shrimp crackers

As the shrimp crackers prepared with $10 \%$ SSP obtained best textured products acceptable by the panelists, these were stored at refrigeration temperature $\left(5^{\circ} \mathrm{C}\right)$ and at room temperature $\left(28-30^{\circ} \mathrm{C}\right)$ for 90 days to observe their shelf life. Aerobic plate count was done by spread plate count method. The data are presented in Table 8.

Table 8. Effect of the storage period on bacterial load of shrimp crackers prepared from shrimp shell wastes stored at different storage temperature

\begin{tabular}{|c|c|c|c|c|}
\hline Product & $\begin{array}{c}\text { Storage } \\
\text { temperature }\end{array}$ & $\begin{array}{c}\begin{array}{c}\text { Storage time } \\
\text { (days) }\end{array} \\
\end{array}$ & $\begin{array}{r}\text { Bacterial load } \\
\mathrm{CFU} / \mathrm{g} \\
\end{array}$ & Log CFU/g \\
\hline \multirow{12}{*}{ Shrimp crackers } & \multirow{7}{*}{$5^{\circ} \mathrm{C}$} & 0 & $1.58 \times 10_{3}$ & 3.19 \\
\hline & & 7 & $1.78 \times 10_{3}$ & 3.25 \\
\hline & & 15 & $3.8 \times 10_{3}$ & 3.57 \\
\hline & & 30 & $4.8 \times 10_{4}$ & 4.68 \\
\hline & & 40 & $6.38 \times 10_{5}$ & 5.80 \\
\hline & & 45 & $8.56 \times 10_{5}$ & 5.93 \\
\hline & & 50 & $2.1 \times 10_{7}$ & 7.32 \\
\hline & \multirow{5}{*}{$28-30^{\circ} \mathrm{C}$} & 0 & $1.58 \times 10_{3}$ & 3.19 \\
\hline & & 7 & $5.93 \times 10_{3}$ & 3.77 \\
\hline & & 15 & $2.3 \times 10_{4}$ & 4.36 \\
\hline & & 30 & $2.1 \times 10_{5}$ & 5.32 \\
\hline & & 40 & $3.8 \times 10_{7}$ & 7.57 \\
\hline
\end{tabular}


Bacterial loads $(\mathrm{CFU} / \mathrm{g})$ of shrimp crackers in both room $\left(28-30^{\circ} \mathrm{C}\right)$ and refrigerated temperatures $\left(5^{\circ} \mathrm{C}\right)$ were increased throughout the storage period. Initial bacterial load of shrimp crackers prepared from shrimp shell wastes was $1.58 \times 10^{3} \mathrm{CFU} / \mathrm{g}$. Bacterial growth at room temperature rapidly increased with the progress of storage time.

On the other hand, in case of the same shrimp crackers kept at refrigeration temperature, bacterial growth pattern was somewhat different. In this case, rate of bacterial growth was slower and up to 7 days storage no big change was observed in APC. After 7 days at refrigeration temperature, bacterial growth gradually increased and after 45 days the APC reached to $2.1 \times 10^{7} \mathrm{CFU} / \mathrm{g}$ which was unacceptable for consumption.

Therefore the results showed that the products made with $10 \%$ shrimp shell powder had an acceptable bacterial load in refrigeration for up to 45 days and in room temperature for up to 30 days.

\section{Conclusion}

It was observed that the flavor, texture and overall acceptability of shrimp crackers produced by incorporating $10 \%$ SSP was more acceptable by the panelists. Study reveals that trade with value added products like shrimp crackers at the domestic market has a very good prospect as it would bring economic benefit to the producer. From the findings of the above study the following conclusions could be drawn:

1. Utilization of the shrimp wastes could minimize the cost of waste disposal that would realize substantial savings

2. Shrimp shell powder could be a remarkable source of high quality protein, because of its abundance and low cost. Value added product like protein fortified shrimp crackers could be prepared from unutilized shrimp shell wastes

3. Shrimp crackers could be served as a high quality protein source for the people suffering from malnutrition

4. Shrimp shell powder may be used in other food items for protein enrichment.

\section{References}

AOAC. 1990. Official Methods of Analysis.. Association of Official Analytical Chemists, Washington, DC, USA. $15^{\text {th }}$ ed.

Bligh, E.G. and Dyer, W.J. 1959. A Rapid Method of Total Lipid Extraction and Purification. Can. J. Biochem. Phys. 37 : $911-917$.

Chotiyanavong, A. 1981. Analysis of fishery products, M.S Thesis, Kasetsart University,Bangkok.

DoF. 2009. Jatio Matsha Pakkha 2009. Department of Fisheries, Bangladesh.

Gordon, D.T., and G.L. Roberts, J. 1977. Agric. Food Chem. 25.

Irianto, H.E. and Giyatmi 1997. Post harvest technology of shrimp: Review of Indonesian experience. J. Aquatic Food Product Technol. 6: 5-20.

Jacquot, R. 1961. In: Fish as Food,. Ed. by G. Borgstrom, Academic Press, New York, London.1:6

Kinsella, J.E. 1988. Food Technol., $42: 145$

Ludorff, W. and Meyer, V. 1973. Fische und Fischerzeugnisse. Paul Parey Verlag, Hamburg- Berlin.

Nowsad, A. 2005. End of Assignment Report-Marine Fish Processing and Product Development. Food and Agriculture Organization of the United Nations, Dhaka, $77 \mathrm{pp}$.

Patcharee, T. and Nongnuch, R. 1990. Production of flavoring agent from shrimp heads. Kasetsart University, Bangkok.

Revanker, G.D. 1978. Sea Food Export Journal 10, May. Avi Publishing Company, Inc.

Shahidi, F. 1994. In: Sea Foods: Chemistry, processing, technology and quality, Ed. by F. Shahidi and J. R. Botta. Blackie Academic and Professional, London, New York.. 320- 333 pp.

Siddika Kabir. 2004. Siddika Kabir's recipe. Bangla Academy, Dhaka. Bangladesh.

Suparno and Nurcahya, S.F. 1984. Utilization of shrimp waste: I. Preparation of shrimp loaves, Res. Rep. Fish. Technol. 28:1-7.

Suparno and Susana. 1984. Utilization of shrimp waste: II. Preparation of shrimp hydrolysate by acid hydrolysis, Res. Rep. Fish. Technol. 28:9-16.

Suparno and Poernomo. A. 1992. Fish waste utilization in Indonesia. Asean Food Journal. 7 (2): 67- 72. 